\title{
Hubungan Variabel Pemasaran Digital Terhadap Electronic Word Of Mouth (E-WOM): Sebuah Studi Literatur
}

\author{
Novi Tri Hariyanti ${ }^{1 *}$, Edwin Meinardi Trianto ${ }^{2}$, Alexander Wirapraja ${ }^{3}$ \\ ${ }^{1,2}$ Program Studi Manajemen Informatika, Institut Informatika Indonesia Surabaya, Jawa Timur \\ ${ }^{3}$ Program Studi Sistem Informasi, Institut Informatika Indonesia Surabaya, Jawa Timur

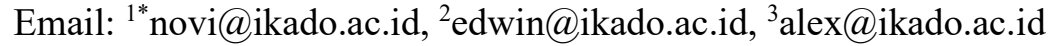

(Naskah masuk: 1 Okt 2020, direvisi: 14 Okt 2020, diterima: 19 Okt 2020)

\begin{abstract}
Abstrak
Pemasaran adalah bidang keilmuan yang menarik dan dilengkapi dengan aspek digital menjadikan pemasaran digital sebagai salah satu bidang keilmuan yang memiliki cakupan yang sangat besar, terlebih dengan mengaitkannya kepada keterlibatan konsumen. Pada penelitian terdahulu didapatkan variabel-variabel penelitian yang digunakan untuk mengukur kepuasan dari konsumen, maka dengan menggunakan metode penelitian studi literatur peneliti menemukan variabel-variabel yang dianggap dapat digunakan untuk mengukur persepsi konsumen dari sisi kualitas website, kepuasan dan keinginan konsumen untuk berbagi dengan konsumen lainnya, dengan memanfaatkan literatur ilmiah antara rentang waktu tahun 2015-2020. Hasil pemetaan literatur yang dilakukan didapatkan hasil bahwa variabel yang secara umum digunakan dalam penelitian pemasaran digital adalah kualitas website untuk mengukur kehandalan dari situs, kepuasan konsumen yang diungkapkan secara elektronik (esatisfaction), kualitas informasi yang diberikan oleh situs dan keinginan konsumen untuk berbagi pengalaman pengunaannya kepada konsumen lain (E-WOM). Selain variabel didapatkan pula metode yang sering digunakan dalam penelitian pemasaran digital adalah menggunakan metode kuantitatif dengan pendekatan Structural Equation Modelling (SEM).
\end{abstract}

Kata Kunci: Pemasaran Digital, Studi Literatur, E-WOM

\section{The Relationship of Digital Marketing Variables to Electronic Word Of Mouth (E-WOM): A Literature Study}

\begin{abstract}
Marketing is an interesting scientific field and is equipped with digital aspects, making digital marketing one of the scientific fields that has a very large scope, especially by relating it to consumer engagement. In previous research, it was found that the research variables used to measure the satisfaction of consumers, then by using the research method of the literature study, this researcher found variables that are considered to be used to measure consumer perceptions in terms of website quality, satisfaction and consumer desire to share with consumers. Others, by utilizing the scientific literature between year 2015 -2020. The results of the mapping showed that the variables, that are generally used in digital marketing research, are the quality of the website to measure the reliability of the site, consumer satisfaction expressed electronically (e-satisfaction), the quality of information provided by the site and the desire of consumers to share their experience of using it to the other consumers (EWOM). In addition to variables, a method that is often used in digital marketing research is to use quantitative methods with the Structural Equation Modeling (SEM) approach.
\end{abstract}

Keywords: Digital Marketing, Literature Study, E-WOM

TEKNIKA, Volume 9(2), November 2020, pp. 146-155

DOI: $10.34148 /$ teknika.v9i2.299

ISSN 2549-8037, EISSN 2549-8045 


\section{PENDAHULUAN}

Pesatnya perkembangan teknologi dan paradigma perubahan cepat yang dialami oleh konsumen secara tidak langsung memaksa perusahaan untuk ikut berubah. Terlepas dari bidang produk maupun jasa pada era saat ini, maka sudah waktunya turut melibatkan pemanfaatan jaringan internet sebagai salah satu alat bantu mereka dengan mengintegrasikan lingkungan bisnis yang dimiliki, seperti konsumen, data dan informasi dalam jumlah besar, komunitas fisik dan virtual, serta lingkungan internal dan eksternal yang berpengaruh secara langsung terhadap perusahaan [1].

Lingkungan bisnis sudah waktunya beralih dari era kompetisi memasuki era kolaborasi. Kolaborasi yang dimaksud adalah adanya hubungan antara konsumen dan perusahaan yang dapat terjalin baik dengan syarat bila perusahaan mampu untuk memuaskan konsumennya. Konsumen yang puas akan membagikan perasaan mereka kepada konsumen lainnya, berbagi perasaan melalui media elektronik ini yang disebut dengan E-WOM [2]. Konsep EWOM merupakan konsep interaksi $\mathrm{C} 2 \mathrm{C}$ atau interaksi antar konsumen dan dengan semakin berkembangnya media sosial, konsumen tidak perlu lagi menyampaikan perasaan mereka secara langsung tapi dapat dengan cara menuliskan ulasan dan review terhadap sebuah produk dan jasa sehingga dapat mempengaruhi pandangan dari calon konsumen lainnya. Hal seperti ini yang turut membuat E-WOM oleh para ahli diyakini menjadi bentuk strategi pemasaran yang efektif dan kredibel [3]. Terciptanya kepuasan pelanggan dapat memberikan beberapa keuntungan antara lain hubungan perusahaan dengan pelanggannya menjadi harmonis, memberikan dasar yang baik untuk pembelian kembali dan menciptakan loyalitas pelanggan, serta membentuk rekomendasi dari mulut ke mulut yang dapat menguntungkan perusahaan [4]. Hal ini berarti bahwa syarat utama dalam membentuk E-WOM yang baik adalah dengan terlebih dahulu memuaskan konsumen. Kepuasan secara elektronik yang dimaksud adalah saat konsumen mendapatkan tanggapan secara tepat, mampu melihat informasi yang diberikan dengan akurat dan tepat, penggunaan platform seperti website yang mudah merupakan unsur penting dalam meningkatkan kualitas pengalaman konsumen sebelum memutuskan untuk melakukan transaksi [5]. Dimensi dari kualitas sebuah website bisa diukur dengan mengacu kepada dimensi kemudahan pengguna, dimensi kualitas informasi, dan dimensi kualitas interaksi [6].

Masalah yang timbul hingga saat ini adalah ditemukan fakta bahwa belum banyak perusahaan yang menyadari efektifitas dalam memanfaatkan teknologi internet dalam aktivitas pemasarannya. Dengan jangkauan yang lebih luas, maka sejatinya akan meningkatkan pangsa pasar perusahaan. Selain itu cara ini akan lebih baik daripada menggunakan cara pemasaran secara konvensional yang terbatas pada jarak, waktu, lokasi, dan jangkauan pengguna [7].

Berdasarkan penjelasan latar belakang masalah di atas, maka tujuan penelitian ini adalah untuk membantu memahami efektivitas dari penggunaan variabel seperti kualitas website, kualitas informasi, kepuasan elektronik dan E-WOM. Hal ini dilakukan melalui analisis model, analisis dan pengembangan kerangka penelitian berdasarkan tinjauan penelitian terdahulu, serta mengamati perbedaan dari konsep pemasaran tradisional dan pemasaran digital, serta dapat memahami pola perilaku konsumen yang berdampak pada niat untuk menyebarkan informasi. Hasil akhir yang diharapkan adalah penelitian ini dapat membantu perusahaan dalam menentukan variabel pengukuran persepsi konsumen untuk memperluas jaringan pemasaran mereka [8]. Maka rumusan pertanyaan penelitian adalah sebagai berikut:

RQ 1. Bagaimana mengumpulkan artikel yang terkait dengan variabel yang akan digunakan agar dapat memberikan pemahaman yang komprehensif dan membantu menentukan penyusunan kerangka penelitian?

RQ 2. Bagaimana gambaran mengenai perilaku konsumen dan memutuskan metode terbaik yang akan digunakan dalam mengukur persepsi dan perspektif konsumen?

\section{METODE PENELITIAN}

A. Identifikasi dan Pengelompokan Literatur

Analisis yang cermat atas bidang penelitian membutuhkan tinjauan pustaka yang sistematis dan terstruktur. Langkah utama yang penting adalah pemilihan sumber dan strategi pencarian. Pemilihan sumber mengacu pada publikasi mana yang harus ditargetkan, misalnya dengan mencari pada jurnal dan konferensi. Sedangkan strategi pencarian mengacu pada definisi istilah pencarian dan bidang pencarian serta jangka waktu yang akan dibahas [9]. Alur tahapan dalam melakukan studi literatur pada penelitian ini adalah dengan menggunakan tahapan seperti pada Gambar 1 berikut ini:

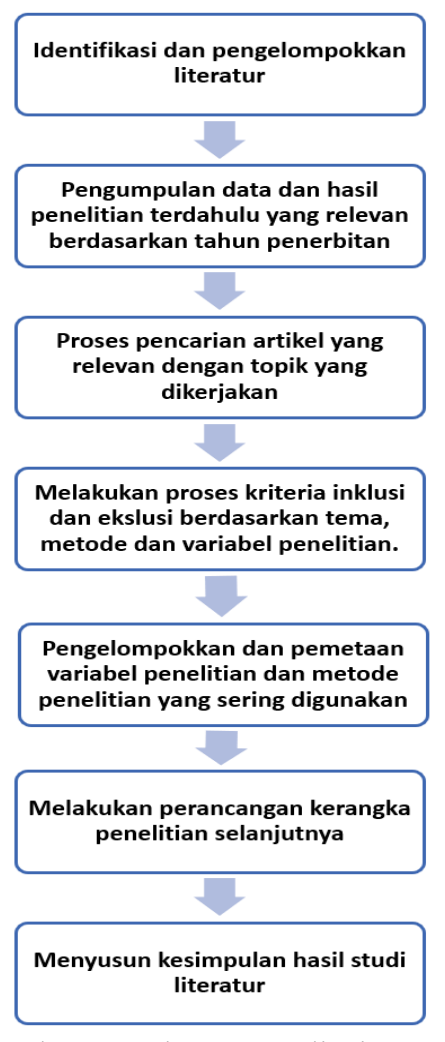

Gambar 1. Tahapan Studi Literatur 


\section{Pengumpulan data}

Penelusuran literatur dilakukan untuk memilih literatur yang diterbitkan antara tahun 2015 hingga 2020. Artikel yang dikumpulkan difokuskan pada jurnal penelitian ilmiah yang diterbitkan secara nasional dan internasional seperti Emerald Insight, IEEE, Springer, Portal Garuda dan Science Direct. Artikel ditemukan terkait dengan aspek e-commerce dan variabel yang terkait dengan penelitian ini. Hal ini dilakukan dengan melakukan pencarian literatur menggunakan kata kunci yang berhubungan dengan bidang E-Commerce, Social Commerce, kualitas website, kualitas informasi, kepuasan konsumen, dan E-WOM. Penelusuran literatur juga melibatkan artikel dari buku-buku referensi dan buku ajar yang dianggap relevan dengan topik yang akan dibahas.

\section{Proses pencarian}

Proses pencarian dilakukan dengan mencari sumbersumber yang berfokus pada jurnal ilmiah yang diterbitkan secara nasional maupun internasional. Sementara artikel dan data statistik juga disertakan dalam studi literatur ini tetapi dengan jumlah proporsi yang lebih sedikit. Sedangkan untuk tahun penerbitan jurnal yang digunakan memiliki rentang antara tahun 2015 hingga 2020 seperti pada gambar 2 dan semua artikel terpilih mengutamakan tema yang berkaitan dengan variabel yang akan digunakan dari proses pencarian dan proses seleksi yang telah dilakukan ditemukan sebanyak 144 artikel terkait

\section{Kriteria Inklusi dan Pengecualian}

Pemilihan kata kunci yang terkait dengan pemasaran digital, perilaku konsumen, kualitas informasi, kepuasan elektronik, word-of-mouth secara elektronik, analisis persepsi konsumen digital, dan kualitas website/situs adalah untuk menyoroti publikasi yang memiliki relevansi langsung dengan pemanfaatan website sebagai sarana pemasaran untuk menarik perhatian konsumen. Padahal istilah umum terkait marketing digital hanya bersifat eksklusif untuk memperkuat teori-teori yang ada. Sedangkan beberapa tema penelitian yang masih terkait dengan pemasaran digital seperti metode pengembangan sistem, dan metode pemasaran konvensional tidak disertakan.

\section{B. Data Sintesis}

Sintesis data bertujuan untuk menunjukkan distribusi topik yang terkait dengan pemasaran digital yang dilakukan oleh pelaku usaha dalam melakukan kegiatan pemasaran dan hasilnya ditampilkan dalam bentuk pemetaan. Menurut Han, $\mathrm{Xu}$, dan Chen tahun 2018 tujuan tahap ini adalah untuk mengurutkan setiap artikel secara akurat untuk mencatat informasi yang akan diperoleh dari setiap makalah yang dipilih [10]. pada penelitian ini peralatan yang digunakan adalah Mendeley dan Microsoft Excel untuk mengumpulkan dan mengintegrasikan data yang berkaitan dengan topik penelitian yang berkaitan dengan variabel-variabel penelitian dalam bentuk judul penelitian, tema penelitian, teori dan variabel yang digunakan, metode penelitian, tahun pelaksanaan, dan hasil yang diperoleh.

\section{Tema penelitian}

Menentukan tema penelitian berguna untuk memahami pengetahuan pembahasan yang berkaitan dengan pemanfaatan variabel digital marketing untuk mengukur persepsi konsumen perusahaan dagang. Dalam beberapa artikel ilmiah terkadang terdapat beberapa tema penelitian yang saling berkaitan satu sama lain. Pada penelitian ini, peneliti tidak membatasi jenis perusahaan yang digunakan, melainkan lebih memfokuskan pada penggunaan variabel penelitian yang akan digunakan dalam pengembangan penelitian ini selanjutnya, seperti variabel kualitas website, kualitas informasi, kepuasan elektronik, dan word-of-mouth secara elektronik. Selain topik yang menjadi kategori utama, peneliti juga menambahkan sub kategori yang akan digunakan dengan melakukan pencarian terhadap artikel-artikel ilmiah lainnya yang tidak secara spesifik berkaitan dengan tema penelitian dengan tujuan untuk memperkuat teori dan konsep yang akan dibahas.

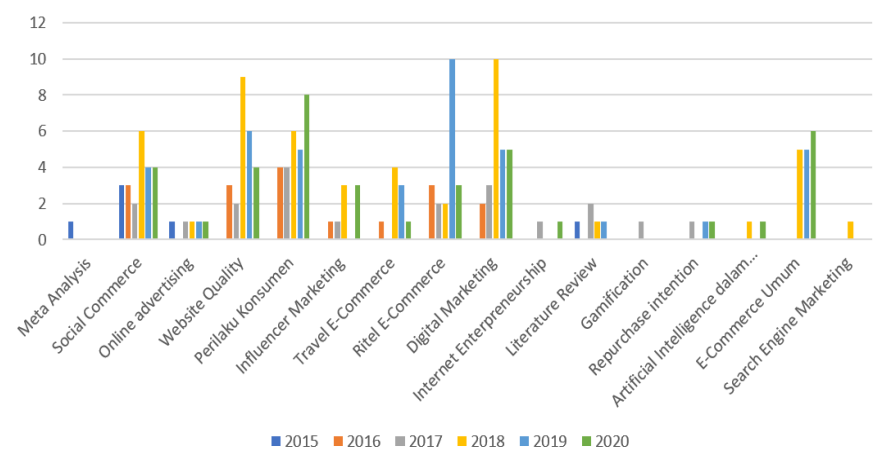

Gambar 2. Pengelompokkan Tema Artikel

Pengelompokkan artikel ilmiah dilakukan dengan mencari tema yang sesuai dengan penelitian yang akan dilakukan. Dalam mengelompokkan tema artikel, peneliti menemukan fakta bahwa banyak jurnal ilmiah yang memiliki tema yang lebih dari satu. Contohnya penelitian yang mengukur persepsi konsumen namun di awal penelitian juga dilakukan penelitian untuk mengukur ketepatan kebijakan strategi pemasaran digital yang diterapkan pada perusahaan bisnis tersebut.

Tema artikel yang didapatkan terkait dengan implementasi strategi pemasaran secara digital seperti Gambar 2 didapatkan hasil bahwa dalam melakukan pemasaran digital dilakukan banyak penelitian terhadap pemanfaatan sosial media sebagai media pemasaran atau yang dikenal dengan istilah social commerce. Tema-tema lain seperti pemanfaatan e-commerce juga banyak dilakukan pada penelitian terutama pada industri ritel dan travel.

\section{Teori Dasar}

Perilaku konsumen dalam konteks perdagangan sosial menjadi salah satu aspek penting bagi perusahaan atau pemasar yang bertujuan untuk mempengaruhi konsumen dengan memanfaatkan perasaan yang dialami konsumen baik sebelum maupun sesudah bertransaksi. Untuk memahami perilaku konsumen dan memprediksi hasil seperti definisi teori kognitif sosial di mana orang cenderung melakukan perilaku tertentu ketika mereka mengharapkan antara manfaat dan kesesuaian yang diperoleh sesuai dengan ekspektasi yang diinginkan. Oleh 
karena itu perlu dilakukan pemetaan terkait variabel yang biasa digunakan oleh peneliti sebelumnya dari literatur yang telah didapatkan dalam penelitian pemasaran digital untuk melihat variabel yang akan digunakan untuk mengukur persepsi konsumen.

\section{HASIL DAN PEMBAHASAN}

A. Bagaimana mengumpulkan artikel yang terkait dengan variabel yang akan digunakan agar dapat memberikan pemahaman yang komprehensif dan membantu menentukan penyusunan kerangka penelitian?

Dalam mengumpulkan artikel untuk memilih artikel yang relevan, dilakukan pemeriksaan terhadap judul, abstrak, dan relevansi artikel pada topik-topik yang berkaitan dengan pertanyaan penelitian. Data ditemukan sekitar 1427 artikel dan setelah diurutkan, untuk memperoleh artikel dan literatur yang relevan dengan pemanfaatan digital marketing dalam bidang pemasaran untuk meningkatkan penjualan pada industri baik umkm maupun industri menengah. Setelah melakukan pemilihan artikel maka langkah selanjutnya adalah pelaksanaan prosedur pencarian ini dari 35.000 jurnal yang ada. Pencarian kemudian dicocokkan dengan pemilihan tema dan variabel sehingga diperoleh 531 jurnal dan dikelompokkan lebih detail melalui penelitian yang menghubungan variable-variabel terkait sehingga diperoleh total 124 jurnal dan sisanya sebanyak 20 adalah literatur pendukung seperti buku, data sekunder, dan artikel.

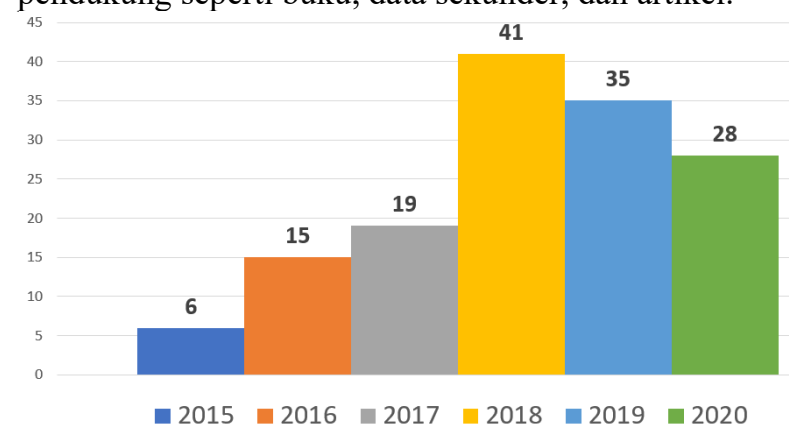

Gambar 3. Jumlah Publikasi Jurnal

Dari jumlah literatur yang didapatkan sebagian besar berasal dari jurnal ilmiah, baik nasional maupun internasional. Untuk jumlah publikasi jurnal ilmiah yang digunakan telah dipetakan seperti Gambar 3. Alasan pemilihan jurnal ilmiah sebagai sumber literatur utama karena jurnal merupakan karya ilmiah yang dapat dipertanggungjawabkan dan secara materi dianggap memiliki isi dan konten yang terbaharui sesuai dengan perkembangan pemasaran digital dari tahun ke tahun.

Pada Tabel 1 adalah rincian dan nama dari penerbit yang telah menerbitkan artikel penelitian ilmiah yang terkait dengan penelitian ini. Adapun nama jurnal dan jumlah yang ada pada Tabel 1 merupakan gabungan dari jurnal ilmiah internasional dan jurnal nasional.

Tabel 1. Hasil Pencarian Literatur Ilmiah

\begin{tabular}{|c|c|c|c|}
\hline Jurnal/Prosiding & $\begin{array}{l}\text { Jumlah } \\
\text { Artikel }\end{array}$ & Jurnal/Prosiding & $\begin{array}{l}\text { Jumlah } \\
\text { Artikel }\end{array}$ \\
\hline $\begin{array}{l}\text { VINE Journal of Information and Knowledge } \\
\text { Management Systems }\end{array}$ & 2 & Journal of Marketing Research & 1 \\
\hline TQM Journal & 1 & $\begin{array}{l}\text { Journal of Information Technology and } \\
\text { Computer Science }\end{array}$ & 1 \\
\hline Tourism Review & 1 & $\begin{array}{l}\text { Journal of Information Systems Engineering } \\
\text { and Business Intelligence }\end{array}$ & 1 \\
\hline The Journal of Accounting and Finance & 1 & Journal of Hospitality and Tourism Technology & 1 \\
\hline $\begin{array}{l}\text { The International Technology Management } \\
\text { Review }\end{array}$ & 1 & Journal of Cleaner Production & 2 \\
\hline $\begin{array}{l}\text { Telkomnika (Telecommunication Computing } \\
\text { Electronics and Control) }\end{array}$ & 1 & Journal of Business Research & 5 \\
\hline Telematics and Informatics & 3 & Internet Research & 3 \\
\hline Technological Forecasting and Social Change & 3 & $\begin{array}{l}\text { International Journal of Systems Assurance } \\
\text { Engineering and Management }\end{array}$ & 1 \\
\hline Spanish Journal of Marketing - ESIC & 3 & International Journal of Research in Marketing & 2 \\
\hline Public Relations Review & 2 & $\begin{array}{l}\text { International Journal of Information } \\
\text { Management }\end{array}$ & 4 \\
\hline $\begin{array}{l}\text { Paradigma: Jurnal Komputer dan Informatika } \\
\text { Universitas Bina Sarana Informatika }\end{array}$ & 1 & $\begin{array}{l}\text { International Journal of Hospitality } \\
\text { Management }\end{array}$ & 4 \\
\hline Jurnal Profit & 1 & $\begin{array}{l}\text { International Journal of Economics, Commerce } \\
\text { and Management }\end{array}$ & 1 \\
\hline $\begin{array}{l}\text { National Conference of Creative Industry: } \\
\text { Sustainable Tourism Industry for Economic } \\
\text { Development }\end{array}$ & 1 & $\begin{array}{l}\text { International Journal of Contemporary } \\
\text { Hospitality Management }\end{array}$ & 1 \\
\hline
\end{tabular}



Word of Mouth (E-WOM): Sebuah Studi Literatur

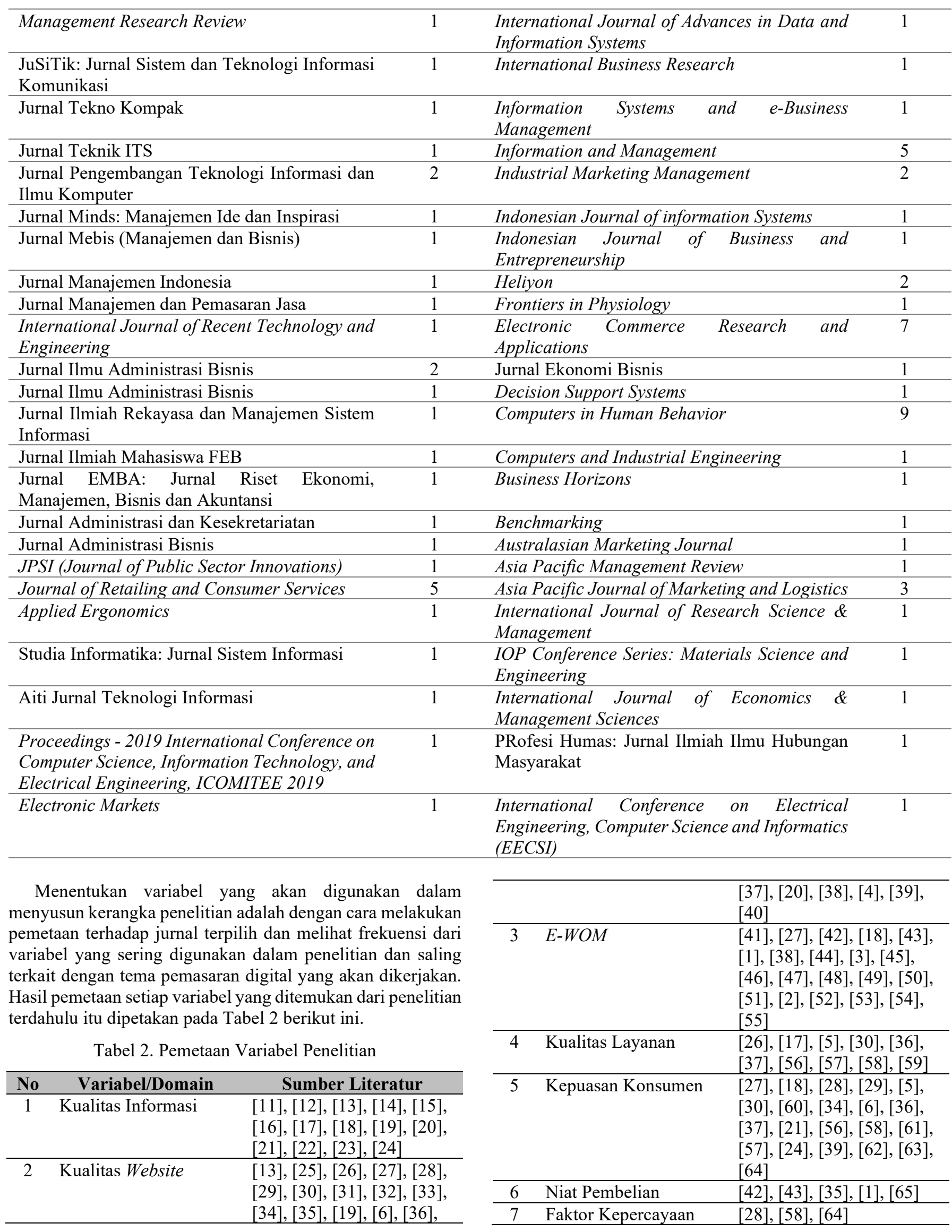




\begin{tabular}{cll}
\hline 8 & Faktor Loyalitas & {$[5],[66],[58]$} \\
\hline 9 & Minat Pembelian & {$[8],[67],[60],[21],[56]$} \\
& Ulang & \\
\hline 10 & Internet of Things & {$[68],[18]$} \\
\hline
\end{tabular}

Dari hasil pemetaan penelitian terdahulu yang terdapat pada Tabel 3, maka didapatkan hasil bahwa variabel yang paling sering digunakan dalam penelitian pemasaran digital marketing adalah kualitas website, kualitas informasi, kepuasan elektronik dan E-WOM. Oleh karena itu peneliti merumuskan model penelitian yang bisa digunakan untuk mengukur tingkat persepsi dari konsumen dengan menggunakan variabel-variabel tersebut dengan membentuk dengan hubungan antar variabel seperti pada Gambar 4 berikut ini:

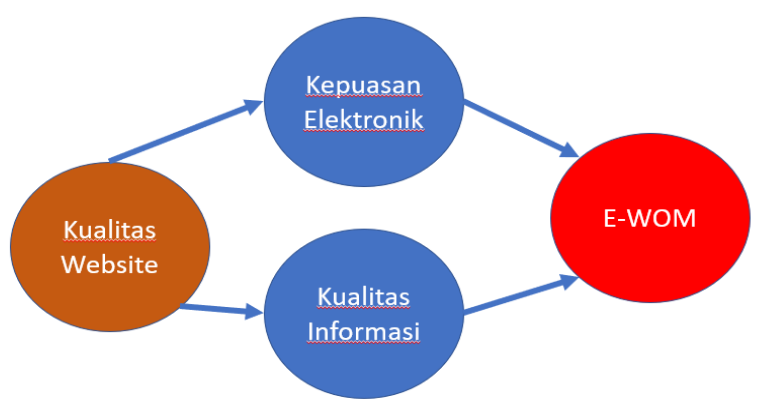

Gambar 4. Kerangka Penelitian

Gambar 4 menunjukkan kerangka atau gambaran yang diusulkan mengenai hubungan antar variabel yang dianggap cocok untuk melakukan penelitian selanjutnya yaitu melakukan pengukuran terhadap persepsi konsumen dengan menilai kualitas website yang mempengaruhi kepuasan elektronik dan kualitas informasi serta pada akhirnya menilai apakah konsumen dapat merekomendasikan atau membagikan perasaan mereka baik dan buruknya setelah bertransaksi dengan menggunakan website perusahaan kepada konsumen atau calon konsumen lain. Variabel akhir yang digunakan sebagai tujuan dalam mengukur hubungan ini adalah variabel E-WOM.

B. Bagaimana gambaran mengenai perilaku konsumen dan memutuskan metode terbaik yang akan digunakan dalam mengukur persepsi dan perspektif konsumen.

Gambaran terhadap perilaku konsumen melalui variabel penelitian yang telah didapatkan dari pemetaan penelitian terdahulu dan ditampilkan dalam bentuk hubungan variabel pada Gambar 4 didapatkan hasil bahwa mayoritas konsumen yang menggunakan media digital dalam melakukan transaksi barang, baik produk dan jasa, akan bersedia untuk membagikan perasaan mereka kepada konsumen atau calon konsumen lainnya melalui kolom review dan komentar. Hal ini disebut dengan E-WOM. Setelah mereka mendapatkan pengalaman dari kemudahan menggunakan situs, kualitas informasi yang baik seperti kejelasan informasi, informasi yang relevan, tepat waktu, maka akan terbentuk rasa kepuasan secara elektronik yang ditunjukkan dengan kesediaan mereka dalam membagikannya kepada konsumen lain. Dari hasil pemetaan yang telah dilakukan pada penelitian terdahulu maka peneliti mencari metode dengan frekuensi yang sering digunakan dan terbukti mendapatkan hasil yang signifikan agar dapat disarankan dan digunakan oleh pihak perusahaan untuk mengukur persepsi mengenai perilaku konsumen. Penelusuran metode penelitian ditampilkan dalam Tabel 3 berikut ini.

Tabel 3. Hasil Pemetaan Metodologi Penelitian

\begin{tabular}{|c|c|c|}
\hline No & Metode Penelitian & Sumber Literatur \\
\hline 1 & Studi Literatur & {$[8],[2],[11],[69],[12]$} \\
\hline 2 & SEM-PLS & $\begin{array}{l}{[70],[14],[71],[46],[41],} \\
{[72],[18],[40],[73],[15],} \\
{[74],[63],[23],[71],[59],} \\
{[75],[40],[17]}\end{array}$ \\
\hline 3 & SEM & $\begin{array}{l}{[65],[14],[41],[66],[32],} \\
{[76],[51],[64],[56],[60],} \\
{[47],[3],}\end{array}$ \\
\hline 4 & $\begin{array}{l}\text { Analisa Faktor } \\
\text { Konfirmatori }\end{array}$ & {$[51],[25],[27],[64],[60]$} \\
\hline 5 & Metode Kualitatif & {$[22],[2]$} \\
\hline 6 & $\begin{array}{l}\text { Expentancy } \\
\text { Confirmation } \\
\text { Theory }\end{array}$ & {$[63],[16]$} \\
\hline 7 & Analisis Regresi & $\begin{array}{l}{[34],[39],[35],[6],[29],} \\
{[19],[77],[67]}\end{array}$ \\
\hline 8 & $\begin{array}{l}\text { Analisis fuzzy set / } \\
\text { kualitatif } \\
\text { Komparatif }\end{array}$ & [78] \\
\hline
\end{tabular}

Dari pemetaan pada Tabel 3 ditemukan bahwa secara umum metode penelitian yang banyak digunakan dalam penelitian digital marketing adalah metode SEM. Maka untuk penelitian mengenai pemasaran digital dapat dikembangkan dengan menggunakan metode SEM dengan teknik sampling adalah purposive sampling yaitu dengan memberi proporsi yang sama kepada sampel untuk dipilih sesuai dengan kebutuhan yang diinginkan pada penelitian tersebut [30].

\section{KESIMPULAN}

Studi literatur yang dilakukan terhadap 144 artikel ilmiah yang didapatkan dari penelitian terdahulu meliputi jurnal ilmiah baik nasional maupun internasional, dan didukung oleh sumber literatur lainnya seperti buku, artikel, dengan mengambil rentang waktu penelitian antara tahun 2015-2020, didapatkan hasil bahwa variabel yang tepat digunakan dalam penelitian pemasaran digital adalah variabel kualitas website, kualitas informasi, kepuasan elektronik dan WOM secara elektronik. Pada penelitian selanjutnya hubungan antar variabel ini dapat diuji dengan menggunakan metode Structural Equation Modelling (SEM). Hasil yang didapatkan adalah hasil analisis perspektif mengenai variabel pembentuk keinginan membagikan perasaan kepada konsumen lainnya yang terbentuk dari persepsi tingkat kepuasan konsumen 
mengenai kegunaan situs perusahaan untuk meningkatkan kekuatan perusahaan dihadapan konsumen melalui komunikasi yang positif antar konsumen.

\section{UCAPAN TERIMA KASIH}

Pada kesempatan ini peneliti mengucapkan terima kasih kepada Direktorat Riset dan Pengabdian Masyarakat, Deputi Bidang Penguatan Riset dan Pengembangan, Kementerian Riset dan Teknologi/Badan Riset dan Inovasi Nasional, Republik Indonesia serta Pusat Penelitian dan Pengabdian Kepada Masyarakat, Institut Informatika Indonesia Surabaya sesuai dengan SK No. 002/SP2H/LT/P3M/IKADO/III/2020 atas Hibah Penelitian Dosen Pemula yang diberikan sehingga kami mampu menyelesaikan jurnal studi literatur yang akan berlanjut kepada penelitian kami berikutnya.

\section{REFERENSI}

[1] Zhao, Y., Wang, L., Tang, H. \& Zhang, Y. (2020). Electronic Word-of-mouth and Consumer Purchase Intentions in Social E-Commerce, Electronic Commerce Research Application, Vol. 41, p. 100980, doi: 10.1016/j.elerap.2020.100980.

[2] Kundu, S. \& Rajan, R.S. (2017). Word of Mouth: A Literature Review. International Journal of Economic and Management Science, Vol. 06, doi: 10.4172/21626359.1000467.

[3] Ryu, S. \& Park, J.K. (2020). The Effects of BenefitDriven Commitment on Usage of Social Media for Shopping and Positive Word-of-mouth. Journal of Retail and Consumer Service, Vol. 55, p. 102094, doi: 10.1016/j.jretconser.2020.102094.

[4] Ardi, A.N.A. \& Yulisetiarini, D. (2018). The Effect of Lazada Website Quality to Satisfaction and Consumer Loyalty. International Journal of Research Science Management, Vol. 5(10), pp. 11-15, doi: 10.5281/zenodo. 1451296 .

[5] Ting, O.S., Ariff, M.S.M., Zakuan, N., Sulaiman, Z. \& Saman, M.Z.M. (2016), E-Service Quality, ESatisfaction and E-Loyalty of Online Shoppers in Business to Consumer Market; Evidence form Malaysia. IOP Conference Series: Material Science and Engineering, Vol. 131(1), doi: 10.1088/1757899X/131/1/012012.

[6] Ardiansyah, I. (2018). Pengaruh Kualitas Website Traveloka Terhadap Kepuasan Konsumen Dengan Menggunakan Metode Webqual. National Conference of Creative Industry: Sustainable Tourism Industry for Economic Development, pp. 5-6, doi: 10.30813/ncci.v0i0.1254.

[7] Oktaviani, F. \& Rustandi, D. (2018), Implementasi Digital Marketing dalam Membangun Brand Awareness. Profesi Humas: Jurnal Ilmiah Ilmu Hubungan Masyarakat, Vol. 3(1). doi: 10.24198/prh.v3i1.15878.
[8] Wirapraja, A. \& Subriadi, A.P. (2019). Effectiveness of Social Commerce in Influencing Repurchase Intention: A Systematic Literature Review. Proceedings-2019 International Conference on Computer Science, Information Technology, and Electrical Engineering, vol. 1, pp. 24-29, doi: 10.1109/ICOMITEE.2019. 8921184.

[9] Baethge, C., Klier, J. \& Klier, M. (2016). Social commerce State-of-the-art and Future Research Directions. Electronics Markets, Vol. 26(3), pp. 269290, doi: 10.1007/s12525-016-0225-2.

[10]Han, H., Xu, H. \& Chen, H. (2018). Social Commerce: a Systematic Review and Data Synthesis. Electronic Commerce Research \& Application, Vol. 30, pp. 38-50, doi: 10.1016/j.elerap.2018.05.005.

[11] Ghasemaghaei, M. \& Hassanein, K. (2015), Online Information Quality and Consumer Satisfaction: The Moderating Roles of Contextual Factors - a MetaAnalysis. Information Management, Vol. 52(8), pp. 965981, doi: 10.1016/j.im.2015.07.001.

[12] Ghasemaghaei, M. \& Hassanein, K. (2016). A Macro Model of Online Information Quality Perceptions: a Review and Synthesis of the Literature. Computer Human Behavior, Vol. 55, pp. 972-991, doi: 10.1016/j.chb.2015.09.027.

[13]Rerung, R.R., Fauzan, M. \& Hermawan, H. (2020). Website Quality Measurement of Higher Education Services Institution Region IV Using Webqual 4.0 Method. International Journal Advances in Data and Information Systems, Vol. 1(2), pp. 89-102, doi: 10.25008/ijadis.v1i2.185.

[14] Syahidi, A.A., Asyikin, A.N. \& Subandi, S. (2019). Measuring User Assessments and Expectations: The Use of WebQual 4.0 Method and Importance-Performance Analysis (IPA) to Evaluate the Quality of School Websites. Journal Information Technology and Computer Science, Vol. 4(1), p. 76, doi: 10.25126/jitecs.20194198.

[15] Rita, P., Oliveira, T. \& Farisa, A. (2019). The Impact of E-Service Quality and Customer Satisfaction on Customer Behavior in Online Shopping. Heliyon, Vol. 5 (10), p. e02690, doi: 10.1016/j.heliyon.e02690.

[16] Yagci, I.A. \& Das, S. (2018). Measuring Design-Level Information Quality in Online Reviews. Electronic Commerce Research Application, Vol. 30, pp. 102-110, doi: 10.1016/j.elerap.2018.05.010.

[17] Putri, W.K. \& Pujani, V. (2019). The Influence of System Quality, Information Quality, E-Service Quality and Perceived Value on Shopee Consumer Loyalty in Padang City. International. Technology Management Review, Vol. 8(1), p. 10, doi: 10.2991/itmr.b.190417.002.

[18] Yu, X., Roy, S.K., Quazi, A., Nguyen, B. \& Han, Y (2017). Internet Entrepreneurship and 'The Sharing Of Information' in an Internet-of-things Context: The Role of Interactivity, Stickiness, E-Satisfaction and Word-Of- 
Mouth in Online SMES' Websites. Internet Research, Vol. 27(1), pp. 74-96.

[19] Khairunnisa, K. \& Wasiyanti, S. (2018). Pengukuran Kualitas Website Pemerintah Depok Terhadap Kepuasan Pengguna Dengan Metode Webqual 4.0. Jurnal Swabumi, Vol. 6(1), pp. 35-43, doi: 10.31294/swabumi.v6i1.3314.

[20] Andayani, S. (2019). Pengaruh Layanan Website Tokopedia Terhadap Kepuasan Konsumen Menggunakan Metode Webqual 4.0. JuSiTik Jurnal Sistem dan Teknologi Informasi Komunikasi, Vol. 2(1), p. 27, doi: 10.32524/jusitik.v2i1.440.

[21]Chen, H.J. (2018). What Drives Consumers' Mobile Shopping? 4Ps or Shopping Preferences?. Asia Pacific Journal of Marketing and Logistics, Vol. 30(4), pp. 797815, doi: 10.1108/APJML-08-2017-0167.

[22] Shang, S.S.C., Wu, Y.L. \& Sie, Y.J. (2017). Generating Consumer Resonance for Purchase Intention on Social Network Sites. Computer Human Behaviour, Vol. 69, pp. 18-28, doi: 10.1016/j.chb.2016.12.014.

[23]Zhou, L., Wang, W., (David) Xu, J., Liu, T. \& Gu, J. (2018). Perceived Information Transparency in B2C ECommerce: An Empirical Investigation. Information Management, Vol. 55(7), pp. 912-927, doi: 10.1016/j.im.2018.04.005

[24] Sthapit, E., Chiappa, G.D., Coudounaris, D.N. \& Bjork, P. (2019). Determinants of The Continuance Intention of Airbnb Users: Consumption Values, Co-Creation, Information Overload and Satisfaction. Tourism Review, Vol. 75(3), pp. 511-531, doi: 10.1108/TR-03-2019-0111.

[25] Jauhari, M.T., Kusumawati, A. \& Nuralam, I.P. (2019). The Impact of Website Quality on Consumer Satisfaction and Purchase Intention (Study Case of E-Commerce Lazada Indonesia in Malang City). Jurnal Administrasi Bisnis, Vol. 67(1), pp. 54-61.

[26] Prasetyo, B., Adnan, F. \& Wardhani, S.A.K. (2018). A Measurement Framework for Analyze The Influence of Service Quality and Website Quality on User Satisfaction (Case Study: an IT Service in Jember University). International Conference on Electrical Engineering, Computer Science and Informatics (EECSI), pp. 56-61, doi: 10.1109/EECSI.2018.8752845.

[27] Tandon, A., Aakash, A. \& Aggarwal, A.G. (2020). Impact of EWOM, Website Quality, and Product Satisfaction on Customer Satisfaction and Repurchase Intention: Moderating Role of Shipping and Handling. International Journal of System Assurance Engineering and Management, Vol. 11, pp. 349-356, doi: 10.1007/s13198-020-00954-3.

[28] Tirtayani, I.G.A. (2018). The Effect of Perceived Website Quality, E-Satisfaction, and E -Trust Towards Online Repurchase Intention. International Journal of Economics, Commerce and Management, Vol. VI(10), pp. 262-287.

[29] Rasli, S., Khairi, N., Ayathuray, H. \& Sudirman, M.S. (2018). The Impact of E-Business Website Quality on
Customer Satisfaction [Online]. Diakses dari: https://www.researchgate.net/publication/329916119.

[30] Chandra, W. \& Wirapraja, A. (2020). "The Effect of Application Usability, Service Quality, and ESatisfaction on Purchase Intention of GoFood Customers. Indonesian Journal Information Systems, Vol. 3(1), pp. 38-49.

[31] Andry, J.F., Christianto, K. \& Wilujeng, F.R. (2019). Using Webqual 4.0 and Importance Performance Analysis to Evaluate E-Commerce Website. Journal of Information Systems Engineering and Business Intelligence, Vol. 5(1), p. 23, doi: 10.20473/jisebi.5.1.2331.

[32] Pee, L.G., Jiang, J. \& Klein, G. (2018). Signaling Effect of Website Usability on Repurchase Intention. International Journal Information Management, Vol. 39, pp. 228-241, doi: 10.1016/j.ijinfomgt.2017.12.010.

[33] Andre, Y. \& Tileng, K.G. (2019). Analisis Kualitas Website Perpustakaan Universitas X Menggunakan Metode Webqual 4.0 dan Importance-Performance Analysis (IPA). Aiti Jurnal Teknologi Informasi, Vol. 16(1), pp. 49-64, doi: 10.24246/aiti.v16i1.49-64.

[34] Kurniawati, R.A., Kusyanti, A. \& Mursityo, Y.T. (2018). Analisis Pengaruh Kualitas Website Terhadap Kepuasan Pelanggan Mister Aladin Dengan Menggunakan Webqual 4.0. Jurnal Pengembangan Teknologi Informasi dan Ilmu Komputer, Vol. 2(3), pp. 1151-1160.

[35] Sastika, W. (2016). Analisis Pengaruh Kualitas Website (WebQual 4.0) Terhadap Keputusan Pembelian Pada Website E-commerce Traveloka. Sentika, Vol. 2016, pp. 18-19.

[36] Aryadita, H., Widyastuti, D.A. \& Wardani, N.H. (2017). Analisis Kualitas Layanan Website E-Commerce Terhadap Kepuasan Pengguna Menggunakan Metode Webqual 4.0. Studia Informatika: Jurnal Sistem Informasi, Vol. 10(1), pp. 29-35, doi: 10.15408/sijsi.v10i1.7747.

[37] Dalilah, I., Kusyanti, A. \& Herlambang, A.D. (2018). Evaluasi Kualitas Layanan Website PT. Kereta Api Indonesia (Persero) Terhadap Kepuasan Pengguna Menggunakan Webqual 4.0 dan ImportancePerformance Analysis (IPA). Jurnal Pengembangan Teknologi Informasi dan Ilmu Komputer, Vol. 2(1), pp. 288-295 [Online]. Diakses dari: http://jptiik.ub.ac.id/index.php/j-ptiik/article/download/754/ 293.

[38] Lestari, N.S. \& Farida, N. (2016). Pengaruh E-Website Quality dan E-Service Quality Terhadap E-Repurchase Intention Melalui E-Word Of Mouth ( E-WOM ) Sebagai Variabel Intervening Pendahuluan Kerangka Teori EMarketing E-Commerce E-Website Quality. Jurnal Ilmu Admistrasi Bisnis, Vol. 9(2), pp. 133-140.

[39] Syaifullah \& Soemantri, D.O. (2016). Pengukuran Kualitas Website Menggunakan Metode Webqual 4.0 (Studi Kasus: CV. Zamrud Multimedia Network). Jurnal 
Ilmu Rekayasa dan Manajemen Sistem Informasi, Vol. 2(1), pp. 19-25.

[40] Ali, F. (2016). Hotel Website Quality, Perceived Flow, Customer Satisfaction and Purchase Intention. Journal Hospitality and Tourism Technology, Vol. 7(2), pp. 213228, doi: 10.1108/JHTT-02-2016-0010.

[41] Erkan, I. \& Evans, C. (2016). The Influence of EWOM in Social Media on Consumers' Purchase Intentions: an Extended Approach to Information Adoption. Computer Human Behavior, Vol. 61, pp. 47-55, doi: 10.1016/j.chb.2016.03.003.

[42] Chen, C.C. \& Chang, Y.C. (2018). What Drives Purchase Intention on Airbnb? Perspectives of Consumer Reviews, Information Quality, and Media Richness. Telematics and Informatics, Vol. 35(5), pp. 1512-1523, doi: 10.1016/j.tele.2018.03.019.

[43] Filieri, R., McLeay, F., Tsui, B. \& Lin, Z. (2018). Consumer Perceptions of Information Helpfulness and Determinants of Purchase Intention in Online Consumer Reviews of Services. Information and Management, Vol. 55(8), pp. 956-970, doi: 10.1016/j.im.2018.04.010.

[44] Siqueira, J.R., Peña, N.G., Horst, E.T. \& Molina, G. (2019). Spreading the Word: How Customer Experience in a Traditional Retail Setting Influences Consumer Traditional and Electronic Word-of-mouth Intention. Electronic Commerce Research and Application, Vol. 37(40), p. 100870, doi: 10.1016/j.elerap.2019.100870.

[45]Cheng, X. \& Zhou, M. (2010). Study on Effect of eWOM: a Literature Review and Suggetions for Future Research. 2010 International Conference Management and Service Science MASS 2010, doi: 10.1109/ICMSS.2010.5576663.

[46] Yadav, M. \& Rahman, Z. (2018). The Influence of Social Media Marketing Activities on Customer Loyalty: a Study of E-Commerce Industry. Benchmarking, Vol. 25(9), pp. 3882-3905, doi: 10.1108/BIJ-05-2017-0092.

[47] Trivedi, S.K. \& Yadav, M. (2018). Predicting Online Repurchase Intentions With E-Satisfaction as Mediator: a Study on Gen Y. VINE Journal Information Knowledge and Management Systems, Vol. 48(3), pp. 427-447, doi: 10.1108/VJIKMS-10-2017-0066.

[48]Li, Y., Wu, R., Li, D. \& Fan, H. (2019). Can Scarcity of Products Promote or Restrain Consumers' Word-ofmouth in Social Networks? The Moderating Roles of Products' Social Visibility and Consumers' SelfConstrual. Computer Human Behaviour, Vol. 95(121), pp. 14-23, doi: 10.1016/j.chb.2019.01.013.

[49] Krishna, A. \& Kim, S. (2020). Exploring Customers' Situational and Word-Of-Mouth Motivations in Corporate Misconduct. Public Relation Review, Vol. 46(2), p. 101892, doi: 10.1016/j.pubrev.2020.101892.

[50] Huete-Alcocer, N. (2017). A Literature Review of Word of Mouth and Electronic Word of Mouth: Implications for Consumer Behavior. Frontiers in Physiology, Vol. 8, pp. 1-4, doi: 10.3389/fpsyg.2017.01256.
[51]Chang, J.H. \& Wang, S.H. (2019). Different Levels of Destination Expectation: The Effects of Online Advertising and Electronic Word-of-mouth. Telematics and Informatics, Vol. 36, pp. 27-38, doi: 10.1016/j.tele.2018.11.004.

[52] Stanton, S.J., Kim, J., Thor, J.C. \& Deng, X. (2019). Incentivized Methods to Generate Electronic Word-ofmouth: Implications for the Resort Industry. International Journal of Hospitality Management, Vol. 78, pp. 142-149, doi: 10.1016/j.ijhm.2018.11.004.

[53]Xiao, Y., Hudders, L., Claeys, A.S. \& Cauberghe, V. (2018). The Impact of Expressing Mixed Valence Emotions in Organizational Crisis Communication on Consumer's Negative Word-of-mouth Intention. Public Relation Review, Vol. 44(5), pp. 794-806, doi: 10.1016/j.pubrev.2018.10.007.

[54] Gibreel, O., AlOtaibi, D.A. \& Altmann, J. (2018). Social Commerce Development in Emerging Markets. Electronic Commerce Research and Applications, Vol. 27, pp. 152-162, doi: 10.1016/j.elerap.2017.12.008.

[55]Lopes, E.L., Freire, O.B.L. \& Lopes, E.H. (2019). Competing Scales for Measuring Perceived Quality in The Electronic Retail Industry: A Comparison Between E-S-Qual and E-TailQ. Electronic Commerce Research and Applications, Vol. 34, p. 100824, doi: 10.1016/j.elerap.2019.100824.

[56] Suhaily, L. \& Soelasih, Y. (2017). What Effects Repurchase Intention of Online Shopping. International Busisness Research, Vol. 10(12), p. 113, doi: 10.5539/ibr.v10n12p113.

[57] Chung, M., Ko, E., Joung, H. \& Kim, S.J. (2020). Chatbot E-Service and Customer Satisfaction Regarding Luxury Brands. Journal Business Research, Vol. 117, pp. 587595, doi: 10.1016/j.jbusres.2018.10.004.

[58] Gotama, F. \& Indarwati, T.A. (2019). The Effects of ETrust and E-Service Quality to E-Loyalty with ESatisfaction as the Mediation Variable (The Study of Bebas Bayar Application User's in Indonesian). Jurnal Minds: Manajemen Ide dan Inspirasi, Vol. 6(2), p. 145, doi: 10.24252/minds.v6i2.9503.

[59] Bernarto, I., Wilson, N. \& Suryawan, I.N. (2019). Pengaruh Website Design Quality, Service Quality, Trust dan Satisfaction Terhadap Repurchase Intention (Studi Kasus: tokopedia.com). Jurnal Manajemen Indonesia, vol. 19(1), p. 80, doi: 10.25124/jmi.v19i1.1987.

[60] Alalwan, A.A. (2020). Mobile Food Ordering Apps: an Empirical Study of The Factors Affecting Customer ESatisfaction and Continued Intention to Reuse. International Journal Information Management, Vol. 50, pp. 28-44, doi: 10.1016/j.ijinfomgt.2019.04.008.

[61] Chen, S.C. \& Lin, C.P. (2019). Understanding The Effect of Social Media Marketing Activities: The Mediation of Social Identification, Perceived Value, and Satisfaction. Technological Forecasting Social Change, Vol. 140, pp. 22-32, doi: 10.1016/j.techfore.2018.11.025. 
[62] Rachman, A. \& Wasiyanti, S. (2019). Pengukuran Kualitas E-Commerce Shopee Terhadap Kepuasan Pengguna. Paradigma Jurnal Komputer dan Informatika Universitas Bina Sarana Informatika, Vol. 21(2), pp. 143-148, doi: 10.31294/p.v20i2.

[63]Liao, C., Lin, H.N., Luo, M.M. \& Chea, S. (2017). Factors Influencing Online Shoppers' Repurchase Intentions: The Roles of Satisfaction and Regret. Information and Management, Vol. 54(5), pp. 651-668, doi: 10.1016/j.im.2016.12.005.

[64] Laureti, T., Piccarozzi, M. \& Aquilani, B. (2018). The Effects of Historical Satisfaction, Provided Services Characteristics and Website Dimensions on Encounter Overall Satisfaction: a Travel Industry Case Study. TQM Journal, Vol. 30(3), pp. 197-216, doi: 10.1108/TQM-072017-0080.

[65] Vahdat, A., Alizadeh, A., Quach, S. \& Hamelin, N. (2020). Would You Like to Shop via Mobile App Technology? The Technology Acceptance Model, Social Factors and Purchase Intention. Australasian Marketing Journal, pp. 1-10, doi: 10.1016/j.ausmj.2020.01.002.

[66] Wu, Y.L. \& Li, E.Y. (2018). Marketing Mix, Customer Value, and Customer Loyalty in Social Commerce: a Stimulus-Organism-Response Perspective, Vol. 28(1).

[67] Chou, S.W. \& Hsu, C.S. (2016). Understanding Online Repurchase Intention: Social Exchange Theory and Shopping Habit. Information Systems and E-Business Management, Vol. 14(1), pp. 19-45, doi: 10.1007/s10257-015-0272-9.

[68]Lo, F.Y. \& Campos, N. (2018). Blending Internet-ofThings (IoT) Solutions Into Relationship Marketing Strategies. Technoogical. Forecasting Social Change, Vol. 137, pp. 10-18, doi: 10.1016/j.techfore.2018.09.029.

[69]Zhang, K.Z.K. \& Benyoucef, M. (2016). Consumer Behavior in Social Commerce: a Literature Review. Decision Support Systems, Vol. 86, pp. 95-108, doi: 10.1016/j.dss.2016.04.001.

[70] Rodríguez, P.G., Villarreal, R., Valiño, P.C. \& Blozis, S. (2020). A PLS-SEM Approach to Understanding E-SQ, E-Satisfaction and E-Loyalty for Fashion E-Retailers in
Spain. Journal of Retailing and Consumer Services, Vol. 57, doi: 10.1016/j.jretconser.2020.102201.

[71] Wilson, N. \& Keni, K. (2018). Pengaruh Website Design Quality Dan Kualitas Jasa Terhadap Repurchase Intention: Variabel Trust Sebagai Variabel Mediasi. Jurnal Manajemen dan Pemasaran Jasa, Vol. 11(2), p. 291, doi: 10.25105/jmpj.v11i2.3006.

[72] Aswani, R., Kar, A.K., Ilavarasan, P.V. \& Dwivedi, Y.K. (2018). Search Engine Marketing is Not All Gold: Insights From Twitter and SEOClerks. International Journal of Information Management, Vol. 38(1), pp. 107-116, doi: 10.1016/j.ijinfomgt.2017.07.005.

[73] Chiu, W. \& Cho, H. (2019). E-commerce Brand: The Effect of Perceived Brand Leadership on Consumers' Satisfaction and Repurchase Intention on E-Commerce Websites. Asia Pacific Journal of Marketing and Logistics, doi: 10.1108/APJML-10-2018-0403.

[74] Shang, S.S.C. (2017). Digital Marketing: A Framework, Review and Research Agenda. Computer Human Behavior, Vol. 81, pp. 160-168, doi: 10.1016/j.indmarman.2017.11.006.

[75] Belver-Delgado, T., San-Martín, S. \& HernándezMaestro, R.M. (2020). The Influence of Website Quality and Star Rating Signals on Booking Intention: Analyzing The Moderating Effect of Variety Seeking. Spanish Journal of Marketing - ESIC, doi: 10.1108/sjme-092019-0076.

[76] Cao, Y., Ajjan, H. \& Hong, P. (2018). Post-Purchase Shipping and Customer Service Experiences in Online Shopping and Their Impact on Customer Satisfaction: an Empirical Study With Comparison. Asia Pacific Journal of Marketing Logistics, Vol. 30(2), pp. 400-416, doi: 10.1108/APJML-04-2017-0071.

[77] Manik, A. (2017). Metode Webqual 4.0 Untuk Evaluasi Kualitas Website Politeknik Negeri Sriwijaya. Prosiding SNATIF Ke- 4 Tahun 2017, pp. 91-96.

[78] Tran, L.T.T., Pham, L.M.T. \& Le, L.T. (2019). Esatisfaction and Continuance Intention: The Moderator Role of Online Ratings. International. Journal of Hospitality Management, Vol. 77, pp. 311-322, doi: 10.1016/j.ijhm.2018.07.011. 